\title{
Networks, Asymmetries and Appropriations: Towards a Typology ${ }^{1}$
}

\author{
Professor Narve Fulsås
}

Institutt for arkeologi, historie, religionsvitskap og teologi (AHR)

Universitetet i Tromsø - Norges arktiske universitet

9037 Tromsø

narve.fulsas@uit.no

Professor Tore Rem

Institutt for litteratur, områdestudier og europeiske språk (ILOS)

Universitetet i Oslo

Postboks 1003

Blindern

0315 OSLO

tore.rem@ilos.uio.no

${ }^{1}$ This article, a revised version of Tore Rem's keynote lecture at the XIVth International Ibsen Conference in Skien on 5-8 September 2018, draws on pp. 140-174 in Narve Fulsås and Tore Rem, Ibsen, Scandinavia and the Making of a World Drama (Cambridge: Cambridge U.P., 2018). This version expands on the theoreticalanalytical framework of our suggested typology, and furthermore adds comparative material on other Scandinavian authors. 
When Bjørnstjerne Bjørnson and Henrik Ibsen first tried to make their way into literary and theatrical markets beyond Scandinavia in the 1860 s, they had no well-trodden paths to follow and few experiences from which to learn. Norwegian literature was in its initial stages of development and unknown to the rest of the world. The early European efforts by this generation of authors were full of failures, disappointments, and new beginnings. Just three decades later, however, things had changed completely. In Germany, Knut Hamsun was a major reason why Albert Langen started up as a publisher in 1893, after Hamsun's first publisher Samuel Fischer had turned down the Norwegian novelist's Mysteries. Langen moved his business to Munich in 1895 and went for contemporary Scandinavian and French writers. In 1896 he married Bjørnson's daughter Dagny, whose sister Bergliot was married to Henrik Ibsen's son Sigurd. These family connections played a role when Langen managed to obtain the rights to Ibsen's new play John Gabriel Borkman (1896), just ahead of Fischer, outmaneuvering his arch rival by offering Ibsen a record fee. Norwegian literature was now 'hot property', in literary as well as commercial terms, being immediately translated, spurring competition among publishers, even forging marital alliances. Not only had the circulation between Scandinavian and major European literatures been intensified, but their temporalities had even been synchronised. New Ibsen plays were now published simultaneously in DanoNorwegian, German and English, soon followed by a series of other languages. Ibsen's new publications in the 1890s probably represented the first 'world events' of world literature (see Fletcher and McFarlane 1976, 500).

Formerly uncharted terrain had, then, been replaced by 'networks'; by multiple points of repetitive contact and interaction connecting authors, domestic publishers, mediators, translators and foreign publishers on a relatively permanent basis. 'Network', however, is a metaphor of democratic interaction between nodes of equal 'thickness' and value, overlooking or underestimating hierarchies and asymmetries (Osterhammel 2014, 711-12). Asymmetries are, on the other hand, at the heart of Pascale Casanova's model of 'world literary space' as a space of rivalry, struggle, and competition (Casanova 2004, 12). In her perspective, there are disparities between national literary cultures in terms of prestige, the power of consecration, and the influence they can have over other literatures. These competitive disparities are largely determined by the 'nobility' ascribed to a nation's literature, which again is determined to a large extent by its age and traditions. To Casanova, France emerged as the winner of this literary competition in the eighteenth century, making 
Paris the 'world literary capital'. In effect, world literary renown was from now on conditioned on being consecrated as 'modern' and 'contemporary' in Paris.

Leaving aside the question of whether 'world literature' is a centered empire, or whether it should rather be seen as multicentred and with distinctive socio-geographic configurations for different genres and historical periods (Moretti 1986, 41), asymmetries are fundamental to its workings. Asymmetries are not least major barriers that have to be overcome when entering world literature from the 'periphery'. Publishing and writing as Bjørnson and Ibsen did within a language area of some 4 to $4 \frac{1}{2}$ million people, without copyright protection, and with little opportunity to intervene directly in their foreign receptions, their way into the world was, from the beginning, characterised by a lack of control. In 1901, William Archer observed: 'In respect of language, Ibsen stands at a unique disadvantage. Never before has a poet of worldwide fame appealed to his worldwide audience so exclusively in translations' (Archer 1901, 54). Not only did Ibsen write in a minor language, the language of this literature was also minor.

Such differences and asymmetries are the reason why we would prefer the term 'appropriation' to the term 'mediation'. While 'mediation' suggests a neutral involvement in transfer processes, 'appropriation' denotes the active use and accommodation of foreign literatures to specific purposes in the target culture. For this reason, a third dimension needs to be taken into account in studying literary transfer processes. In addition to mapping the emergence and maintenance of networks and evaluating the effects of cultural hierarchies, we need to pay attention to the particular structures and cleavages organising each appropriating culture. In each of them, there were struggles over literary value, where Ibsen could be used to confirm established standards or, on the contrary, function as an asset in efforts to overturn them. It was only when Ibsen was appropriated by local agents with a stake in domestic literary and theatrical struggles that his international career started to take off. A sign of his dependency is the great variety entailed in his early European reception, even if we limit our perspective to Germany, France, and, most especially, Britain, that is to what Franco Moretti calls the European 'core' (Moretti 1998, 181). All from the start several distinctly different 'Ibsens' were created, not just from one appropriating culture to another but also within each one. Ibsen was adopted by agents with different and partly competing agendas; the most effective cases of appropriation involved intermediaries with great 'power of consecration' (Casanova 2004, 22). 
The Ibsen case, then, demonstrates that there was not just one kind of relation between peripheral author and appropriating centre, but several different ones, spanning various degrees of subordination or reciprocity. We will suggest a threefold typology of appropriations, distinguishing between 'imperial appropriations', 'radical appropriations', and 'faithful translations'. These partly represent a chronological sequence, forming a trajectory from asymmetry towards a certain equality. Our typology is based on empirical generalizations from the Ibsen case, and more particularly from Ibsen's early European reception, and it does not claim to be all-encompassing even in his case and certainly not for world literature in general. Even so, it might be applicable also in other cases of circulation between literary peripheries and centres. Ahead of this threefold typology we might also add a fourth type: an initial stage characterised by largely unsuccessful, self-initiated export efforts.

\section{Self-initiated mediation}

When Ibsen looked back upon his own practice in 1899, he claimed that 'it is against my inclination to contribute to the distribution of my works' (Letter to D. Grønvold, 14 October 1899). This is in line with how Ibsen's authorial image was received and perceived by modernists such as James Joyce and Rainer Maria Rilke, but it hardly works as an accurate reconstruction of the writer's actual dissemination history. Ibsen's first translations into German were in fact self-initiated. The first of these was Brand, published in Kassel in 1872, and translated by the unknown travelling salesman P.F. Siebold. A letter published as recently as in 2010 shows that the initiative came from Ibsen (Letter to Harald Thaulow, 16 May 1866). In connection with these publication plans, Ibsen also asked his friend Lorentz Dietrichson to provide a biography (Letter, 28 May 1869). The biography was translated by Siebold and published in Illustrierte Zeitung in 1870, two years before Ibsen had found a publisher for the translation.

In the second half of the 1870 s Ibsen went on both to finance and supervise the German translations of Nordische Heerfahrt (The Vikings of Helgeland) (1876), Die Herrin von Oestrot (Lady Inger) (1877) and Stützen der Gesellschaft (Pillars of the Community) (1878), all by Emma Klingenfeld in Munich. Even if these were published as 'authorised', they did not put competitors off, however. This precarious situation may be said to have climaxed with the many productions of Stützen der Gesellschaft in 1878, earning Ibsen almost 
nothing because theatres availed themselves of unauthorised and therefore cheaper translations of the play.

By 1882, when Ibsen applied for an increase in his state grant on the ground that lack of copyright protection led to financial losses abroad, he was able to list eight verse and prose dramas published in fourteen different German versions by eight different translators and seven different publishers (Letter to H.E. Berner, 18 February 1882). Ibsen had a stake in just four; he had soon experienced a loss of control. His early stance, as communicated to the translator Emil Jonas regarding Pillars of the Community in 1878 - 'it should be quite obvious that no parts can be left out in this play nor any line cut' - was clearly unrealistic (Letter, 18 January 1878). The vulnerability was further exposed by the less than successful productions of Puppenheim, or Nora, of 1880, when Ibsen had to provide an alternative, harmonious ending since the only other option was that theatre directors unhappy with the original would do it themselves. These German disappointments, we argue, contributed to making the Norwegian playwright redirect his attention to Scandinavia during 'the Modern Breakthrough' of the early 1880 s. It took time before Ibsen was able to negotiate a patchwork system of agreements and contracts, still without legally being able to claim copyright since the Scandinavian countries, as literary import cultures, decided to stay out of the Bern Convention of 1886 .

\section{Imperial appropriations}

In Germany Ibsen had for a while tried to control his own mediation, but outside of Germany he was dependent on intermediaries beyond his control from the very beginning. He was, we might say, dependent on networks with weak ties, connecting points of unequal thickness and involving persons largely unknown to each other. Some of the early mediators of Ibsen in France and Britain fit into an empire model, appropriating foreign literature and plays in ways which ultimately served to reaffirm the centrality of their own, hegemonic literature and theatre. The products of the periphery were, in these cases, clearly approached from the 'universalist' perspective of the centre or the metropolis. Literature was presented as something 'pure and harmonious', the power relations specific to the literary world were denied, asymmetries erased (Casanova 2004, 43).

In France, Philarète Chasles (1798-1873), professor of foreign, modern literatures at Collège de France, was a typical representative of this approach. Chasles regularly informed 
journal readers of literary news from England and other countries, presenting his own country as the self-evident centre of literature and civilisation: 'What Europe is to the rest of the world, France is to Europe; everything reverberates toward her, everything ends with her' (quoted in Damrosch 2003, 9). In 1870, Chasles planned to give lectures on the new Norwegian literature in Paris, probably inspired by Georg Brandes, who met Chasles regularly during his stay in Paris in the summer of 1870. Ibsen was asked to provide material for him, but the plans came to nothing as the Franco-Prussian war broke out that same autumn.

The first book containing Ibsen's dramas in French (a part of $A$ Doll's House and Ghosts), only appeared in 1889, influenced by the German reception. There was indeed a wave of interest in foreign literature in France from the middle of the 1880s until the middle of the 1890 s, and both the Russians and what was referred to as 'le snobisme ibsénisme' were formative components of the so-called cosmopolitan movement (Shepherd-Barr 1997, 8-9). But the most significant writings on Ibsen at this time came from the leading critic Jules Lemaître, and he was strongly assimilationist. Lemaitre claimed that Ibsen was not as original as was often claimed, noting that what he had 'loved most in them is that in which they are like us. I have travelled enough. I shut and close my door and again become a Latin man and Frenchman' (Nyholm 1959, 13).

In Britain, Ibsen's first mediator was Edmund Gosse. Contrary to Chasles and Lemaître, Gosse had no position in the literary world when he became acquainted with Ibsen. We do not find anything quite similar to French chauvinism in Gosse, but two characteristics nevertheless qualify him for the category of imperial appropriators: he emphasised that Ibsen was acceptable to metropolitan standards, thus smoothly integrating him into existing aesthetic norms; and he used Ibsen to promote his own career within the existing metropolitan hierarchy. The 'relative weakness' of a foreign writer may clearly be used to strengthen the status of an intermediary in the new literary field (Casanova 2004, 158), and Gosse's undertaking was instrumentalist from the beginning. He consciously searched the periphery for resources which he could use to advance his own position. As a young man he had wanted a career in literature and was advised to 'choose something out of the way, Scandinavian literature for example' (Thwaite 1984, 107). In the summer of 1871 the 22 -year old Gosse had therefore travelled to Norway, returning with a copy of Ibsen's Digte (Poems). When he felt able to understand Ibsen's language, he wrote an unsigned review for the Spectator (1872), called 'Ibsen's New Poems'. 
During the 1870s, Gosse went on to translate several poems and even the entire Love's Comedy, without succeeding in interesting publishers in Ibsen's verse drama. But from 1872 to 1879 , Gosse wrote around 20 notes, essays and reviews on Ibsen alone, plus many more on other Scandinavian topics and writers. Gosse's first more substantial piece typically tried to accommodate the Norwegian writer to the centre. Having worked his way through Love's Comedy, Brand and Peer Gynt, Gosse in 1873 posed the question in Fortnightly Review: 'Where shall we look for a young great poet among continental nations?' (Gosse 1873, 74). Gosse could find none; instead, the answer lay to the north: 'It is my firm belief that in the Norwegian, Henrik Ibsen, the representative of a land unknown in the literary annals of Europe, such a poet is found.' The English critic stressed Ibsen's status as 'poet' and his universal qualities, and the claim was that a new Goethe had arrived from the periphery.

This man of letters practically terminated his early Ibsen campaign just when it could have taken off. In November 1880, Ibsen granted Gosse the rights to translate and produce $A$ Doll's House. But by 1879, Gosse had reached his aim of achieving expert status on Northern literature. He was beginning to acquire an extensive network in his own literary field and was ready to move on to greater things, namely English literature (Gross 1969, 177). Pillars of the Community was the last play to receive Gosse's public attention in Britain until The Lady from the Sea nearly ten years later. For most of the 1880s, he kept silent on Ibsen's new contemporary plays. Even when Gosse belatedly turned his attention to the modern prose plays, he continued to refer to Ibsen as 'the Poet', generally avoiding the more mundane 'playwright', while effectively associating Ibsen with Aeschylus and Shakespeare (Gosse 1889, 116).

This perspective of the centre might also of course be used by more or less hostile critics in order completely to exclude Ibsen. When Frederic Wedmore reviewed A Doll's House in 1889, his response was not all negative. He had noted an ongoing battle between what we would call 'radical appropriators' and 'faithful translators', wondering: 'Is he a missionary, or is he an artist, or is he perchance both?' (Wedmore 1889, 419-20). Wedmore ended up pursuing the missionary lead, arguing that everything had already taken place at the centre: 'London is not the place in which the most pressing of our needs is to learn Henrik Ibsen's sapient lesson.' Ibsen's most striking characteristic was not that he was 'suburban' or even 'provincial'; it was that 'he is of Scandinavia'.

Under this category of 'imperial appropriations' we might, furthermore, count the first stage appearances of Ibsen in English, characterized as they were by heavy adaptation and 
domestication in order to fit the norms of metropolitan theatre. The first Ibsen play appearing on the English stage was called Quicksands; or The Pillars of Society, produced for a single matinee performance in 1880. A Doll's House appeared next, in 1884, under the title Breaking a Butterfly, adapted beyond recognition with Anglicised names and a happy ending. Ibsen's first properly commercial West End appearance, An Enemy of the People produced by the actor-manager Herbert Beerbohm Tree in 1893, was also characterized by radical domestication. However, such domestication was not restricted to the hegemonic cultural powers of European. For Italy, Giuliano D'Amico has demonstrated how Ghosts was transformed into a major commercial success with the actor Ermete Zacconi, the production communicating a clear morality (D'Amico 2013, 131-66). Again, such a practice was made possible by the lack of copyright protection.

The first complete translation of an Ibsen play into English also deserves mention here. In her preface to her translation of Emperor and Galilean in 1876, Catherine Ray noted that Ibsen was 'a poet without a tendency', acceptable to and appealing to 'the educated classes' (Ray 1876, iii). Ray thus paratextually stressed cultural acceptability and attempted to integrate Ibsen into already existing social, political, and aesthetic norms.

\section{Radical appropriations}

Radical appropriations, by contrast, are characterised by the use of translated literature in order to challenge and overturn existing social, political and/or aesthetic orders. Radical appropriators want to cause confrontations, ruptures and discontinuities. These appropriators were still largely unknown to the author and beyond his control. They did not take the universality of metropolitan standards for granted, but they appropriated Ibsen for purposes quite distant from something that would have been recognizable in his originating contexts.

A positive, fairly balanced, review of an Ibsen publication in 1890 in The Speaker seems to state what was only obvious at this point in Ibsen's British reception: 'we must never lose sight of the fact that these dramas each and all have their lesson to convey [...] and we cannot help considering Ibsen's plays as being so many sociological, political, and ethical studies of character, individual and social, in addition to [...] being plays for dramatic representation' (Anon 1890, 379-80). 'His every play is a play with a purpose,' the review, called 'Ibsen for the English', concluded. 
Such perceptions have their prehistory in the early British socialist appropriations of Ibsen. The first translation of one of the playwright's modern prose dramas into English belongs in the category of radical appropriations: Henrietta Frances Lord's Nora: A Play, published 1882. In sharp contrast to Ray, Lord's was a strong reading of the political Ibsen. She presented the playwright as a propagandist and more particularly as a 'Woman's Poet' (Lord 1882, vii, xxiii-xxiv). Lord also went on to translate Ghosts, serialised in the socialist magazine To-Day (1885). Such publication contexts of course helped determine and shape both Ibsen's readerships as well as the perceptions with which his work was met.

These radical mediators helped making the 1880 s the decade of the 'socialist Ibsen' in Britain; 'politicised' and 'topical' Ibsen came to replace Gosse's 'world poet'. Lord's translations addressed a socialist-feminist audience hardly found in Scandinavia, but well represented among members of the Fabian Society and other reform and revolutionary organisations. These followers of Ibsen sought confrontation and distinction, and they crucially contributed to making the 'Ibsen battles' in Britain from 1889 until 1893 so heated. It is hard to imagine that some idea of Ibsen 'on his own', or Archer's 'Real Ibsen', would have created the same uproar, or provoked conservative critics to quite the same extent. At the time of his breakthrough around 1889--1890, the British Ibsen had not been established as a poet, in spite of Gosse's efforts. He had instead been tied to particular ideologies, and came to be perceived as subversive both in social and political terms, even seen as a socialist, far removed from his political meanings in his contexts of origin.

Within socialist circles some of the early signs of Ibsen's arrival can be found around 1884, among people like the South African feminist Olive Schreiner, the social reformer Havelock Ellis, Eleanor Marx, Karl Marx' youngest daughter, and Edward Aveling, her common-law husband, as well as George Bernard Shaw. Marx would probably have been made aware of Ibsen through her German connections and Aveling also refers to German translations around this time (Aveling 1884, 475). Aveling's earliest known public involvement in the Ibsen cause was an intervention on behalf of $A$ Doll's House on the occasion of Breaking a Butterfly, and is typical. He lamented that 'rarely has an opportunity, at once literary and dramatic, been so unhappily thrown away', claiming that Ibsen was born to be 'the woman's poet', and that he was a writer wanting to 'aid in the revolutionising' (ibid., 473-74).

These socialists, soon labelled 'Ibsenites', took part in heated debates in London's theatre societies, wrote a number of articles in socialist and theatre journals, and helped 
initiate early productions. They were also engaged in various publishing enterprises. Eleanor Marx went on to translate what she called An Enemy of Society (1888) and The Lady from the Sea (1890), and she also began work on The Wild Duck (Marx, Letter to Brækstad, 8 May and 16 May 1890). As part of a Fabian publishing program, Shaw's The Quintessence of Ibsenism (1891), in its various editions, came to have a particular influence. Shaw presented a spirited and independent interpretation of Ibsen, but also helped build and confirm conservative perceptions of a radical and even socialist playwright. The very term 'quintessence' and Shaw's lack of restraint in speaking of 'messages', as well as his own notoriety as a prominent socialist, contributed to readings, both at first and later, that have certainly been too crude, something of which Joan Templeton has recently reminded us (Templeton 2018). Here we would simply note that this was how Shaw was perceived, even by those who knew him best, such as William Archer.

Along with the construction of a socialist Ibsen, his association with the figure of the New Woman became the most powerfully marked feature of his reception in English from the middle of the 1880s. Lord's Nora had established the connection, and already in 1884, Havelock Ellis's article 'Women and Socialism' brought in Ibsen's 'Nora' (Ellis 1884). Conservative critics would later inherit such labels, habitually referring to 'the socialistic Nora' and 'the Socialist prophet of the North' (Scott 1889A, 19-22). Women generally, and feminists more particularly, came to have a special importance in the early appropriations of Ibsen, as did his female audiences. And there was of course one character who came to prominence more than anyone else. The literary historian Peter Keating observes that 'Excepting Queen Victoria, Ibsen's heroine [Nora] was probably the most famous woman in late Victorian Britain, within literary and intellectual circles at least' (Keating 1989, 167).

There were also radical aesthetic appropriations of Ibsen in several European countries, leading to movements and developments much larger than himself and his own authorship. In France, the first movement associated with Ibsen was that of naturalism. André Antoine and his Théâtre Libre clearly used Ibsen, and Ghosts in particular, to develop their own version of stage naturalism. But Ibsen was almost immediately taken over by their antagonists and avant-garde successors, the symbolists. The director Aurélien Lugné-Poë produced Ibsen in ways very far from Scandinavian conventions, and in ways of which Ibsen himself seems to have been rather sceptical. The Danish writer Herman Bang, not himself averse to experiment, took it upon himself to try to moderate Lugné-Poë's excesses, albeit with limited success (Nyholm 1959, 38-45). In France, Ibsen's association with the theatre 
avant-garde became a lasting one. In Britain, too, Ibsen came to belong mainly to the 'independent', experimental sector of the theatre but there he at the same time experienced a literary success without parallel in France. In Germany, Ibsen was a commercial and artistic success in both the theatre and the book market, much as he was in Scandinavia.

\section{Faithful translators: William Archer}

Ibsen's most important British and English-language mediator came to be William Archer. We highlight Archer as a prominent example of the third kind of mediator, what we call 'faithful translators'. This is not to indicate that we can ever have a translation that exactly replicates the original, that interpretation is not inevitably a part of the transformation from source to target culture, or that we should ignore paying heed to the 'untranslatable' (Apter 2013). But such a term nevertheless signals a concern with fidelity and a commitment to the text, a certain kind of intention (Anon 1897, 41-42). Such an approach stands opposed to both imperial and radical appropriations.

Archer worked as translator, theatre critic, consultant, and partly as organiser of a number of the most important Ibsen productions in the late 1880s and 1890s. Contrary to Gosse, Archer already had a position as an influential theatre critic when he entered into the most decisive phase of his Ibsen campaign by the late $1880 \mathrm{~s}$. Archer, furthermore, had come to discover Ibsen independently of Gosse. His grandfather and uncle's family had settled in Norway, he had gone there for many summer holidays, had spoken Norwegian as a child and then picked it up again in his teens. He first came across Ibsen in 1873, when as a boy of 17 he spent the summer with his uncle. In the autumn of 1881, Archer went to Rome where he met Ibsen on several occasions, and the acquaintance was renewed in the summer of 1887. This earned Archer the playwright's confidence and established a privileged connection which was to be enjoyed by no other British mediator. 'Better than nearly anyone,' Ibsen wrote to the director of London's The Independent Theatre, J.T. Grein in 1891, 'he knows my intentions' (20 February 1891). Archer's intimate knowledge of Ibsen's works and his philological competence would gradually lead to him earning the respect even of hostile critics. He was able to report about a Scandinavian Ibsen to which the great majority of British readers and audiences did not have access.

Being familiar with Scandinavian cultures and languages and at the same time having a position in British theatre and literature were vital premises for Archer's role as 'faithful 
translator'. In contrast to the preceding Ibsen translators and mediators, he had profound linguistic and cultural competence of both contexts of origin and contexts of appropriation and he was committed to doing justice to both. While Archer had been involved in the infamous Quicksands production - it was based on his translation - the really radical move in Archer's career was to take up a faithful approach to theatre translation, and that in regard to a modern and controversial playwright from the periphery. Conservative critics would mock the reverence of the 'Ibsenites' as they turned up in the theatre with Ibsen books in hand. To them, Archer had simply not recognised his duty as adaptor: 'Word for word Mr. Archer has faithfully translated the original play and not allowed one suggestion, however objectionable, to be glossed over', as Clement Scott noted about A Doll's House (Scott 1889B, 3). Archer, who was familiar with Ibsen's status in Scandinavia, treated Ibsen as a modern classic. 'The translation was that of a scholar,' Scott added ironically.

Archer's approach to Ibsen meant treating the relation between originating and target contexts as symmetrical. Translation had to pay due respect to cultural differences, not immediately treating everything foreign as signs of backwardness, and recognising untranslatabilities. For example, in his 'Translator's Note' in the first British edition of John Gabriel Borkman, Archer explained the difficulties of finding an equivalent for the frequently repeated 'opreisning' in the first and second acts. No single English word would fit all the different contexts, and he had ended up employing three: 'redemption', 'restoration', and in one place 'rehabilitation'. He also explained that he had adopted the 'Norwegian practice' of indicating emphasis by 'slightly spacing the emphasis of the emphatic word', since italics exaggerated the emphasis required: 'The Norwegian method may not be pleasing to the unaccustomed eye, but I think it will be found to assist the understanding' (Archer 1897, ixx). Such awareness seems never to have bothered Gosse, whose linguistic incompetence was brutally exposed by Archer on the occasion of Hedda Gabler, nor would it have been a major concern for those wanting Ibsen to 'aid in the revolutionising'.

Archer was close to many of Ibsen's socialist followers, like Shaw, but he was careful to distance himself from the most zealous Ibsenites, always rejecting the notion of 'messages' and the idea of 'Ibsen, the thinker'. He also had a strong agenda of his own, but this was primarily aesthetic and institutional: Archer wanted to revive the native English drama, renew it in the direction of realism, and even create a 'national' theatre, meaning a theatre released from commercial pressure and capable of giving priority to artistic considerations. He wanted to close the gap between literature and theatre, page and stage, which never had been 
separated in Scandinavia as they had in Britain and on the continent. But Archer was intent on winning followers and on adopting a certain moderation and pragmatism in his championing of Ibsen. For that reason, it was vital for him to keep Ibsen at a distance from factional interests.

Archer thus stressed the 'almost Protean' quality of Ibsen's multifaceted dramatic art, arguing, in direct confrontations with the socialists, and not least Shaw, that '[t]here never was a less systematic thinker' (Archer 1892, 456). When he wrote his 'General Preface' to Ibsen's The Collected Works, he characteristically insisted that this foreign playwright was not 'the man of ideas or doctrines', but rather 'the pure poet, the creator of men and women, the searcher of hearts, the weaver of strange webs of destiny' (Archer 1908, xiv-xv). This 'poet', however, represented complexity and a resistance to reductive use, in quite different ways from Gosse's 'universal poet'.

When Archer started his ambitious publishing program on Ibsen's behalf from 1888 onwards, he opted for scholarly attentiveness to the original texts, first launching a series of Ibsen translations with the Newcastle-based publisher Walter Scott, in a series of cheap reprints intended for a popular audience. Most volumes contained three plays, and by 1892 , Archer noted: 'we are well within the mark in estimating that one hundred thousand prose dramas by Ibsen have been bought by the English-speaking public in the course of the past four years. Is there a parallel in the history of publishing for such a result in the case of translated plays?' (Archer 1893, 308). By 1890, William Heinemann took control over new Ibsen publications, initially also reintroducing Gosse to the Ibsen business. This eventually led to Ibsen's Collected Works, published 1906-12. It was in itself extraordinary to have a contemporary foreign playwright's works in English, and it represented a monumental affirmation of Ibsen's English-language canonisation.

Alongside Archer, we must also mention a number of dedicated Ibsen actresses who, often at their own cost, brought a series of artistically successful productions onto the English stage. The first, representing Ibsen's public breakthrough in Britain, was Janet Achurch's $A$ Doll's House in 1889 (followed by a world tour) (Holledge et al., 2016, 35-42). Achurch's commitment to fidelity involved the sensational feature of not changing her dress throughout the performance, thus breaking with the expectations of the Victorian stage. Later, Elisabeth Robins was involved in several important productions, notably Hedda Gabler and The Master Builder. These actresses shared Archer's faithful approach to Ibsen, and also used him as their main consultant, which does not mean that they simply used the published translation in the 
theatre. Robins and her partner Marion Lea set to work altering 'Ibsen's English dress', after which Archer accepted and rejected their suggestions (Robins 1928, 17). Archer, as theatre critic and man of the theatre, clearly had an advantage over more purely literary translators. He was very much aware of the 'added criterion of playability' in theatre translation (Bassnett 2003, 121). The result, according to Robins, was 'a very speakable, very playable version', in fact 'more faithful - to Ibsen', as they saw it. Censorship, parody and not least the urge to avoid involuntary comic effect, also led to omissions. Even so, their approach broke radically with the general tendency to evince 'indifference toward the script' (Cima 1993, 25).

Robins became a feminist and a political activist, but later played this down in relation to her Ibsen work. She even claimed that what Ibsen offered 'had nothing to do with the New Woman; it had everything to do with our particular business - with the art of acting' (Robins $1928,31)$. Ibsen's challenge was associated both with certain constrictions, such as his detailed stage directions and the displacement of traditional plots, and with a new freedom. The latter was exercised in the interpretation of his complex psychology, dialogue, and subtexts, and in his rejection of an easily decodable emotional relationship with stock characters, plus a general openness. ${ }^{2}$ Robins wrote about her choice of 'points' with reference to 'those that Ibsen had left me not merely to make, but to find' (Robins 1928, 48).

\section{From cosmopolitanism to border protection}

Norway's remarkable rise as a 'literary power', moving all the way from the initial stages of creating a national literature to becoming an export nation in just a few decades, was part of and made possible by the overall expansion of world trade in the late nineteenth century. It has been estimated that the value of world trade, at constant prices, increased tenfold between 1850 and 1913, while its volume increased by an annual average of 3.4 percent between 1870 and 1913. The bulk of this trade took place among Europeans or between Europeans and the neo-European settler colonies (Osterhammel 2014, 726). In the world of literature, this expansion manifested itself in the 'inflow' of new, hitherto largely unknown peripheral literatures in the major literatures of Europe, the most notable new 'world literatures' being the Scandinavian and the Russian. Ibsen became the foremost representative of this 'Scandinavian Moment' in world literature, affecting the status of Nordic literature in general.

\footnotetext{
${ }^{2}$ Many thanks to Sos Eltis for her contribution to this argument.
} 
The ascending status of Scandinavian literature had several corollaries. One, as already noted, was synchronization of the temporalities of Scandinavian literature and the temporalities of the appropriating fields. While Ibsen's European breakthrough had largely been a matter of 'catching up' with the Scandinavian 'modern breakthrough', often in a compressed and rather disorganized manner, the situation in the 1890s was that he wrote immediately for an all-European market. This synchronicity would sometimes invite 'younger' Nordic authors to overestimate their potential in foreign fields. When Strindberg came to Paris, he saw himself as representing the latest Nordic trend, only to realise that the 'old' Ibsen and Bjørnson were not at all old in France; in fact they had just arrived. Another Swedish writer operating in Paris in the 1890s, Ola Hanson, used every occasion he could find to try to undermine Bjørnson and Ibsen. He praised Strindberg at their expense, but even more representative of the Nordic countries, he explained to his French readers, were the completely unknown Finns Juhani Aho and Karl August Tavaststjerna, the Swede Gustaf Fröding and the Norwegian Jens Tvedt (Ahlström 1956, 182, 239).

Another corollary of a more equal status was that it allowed a peripheral author to move from being 'honoured' and 'grateful' for being translated to enter into a primarily commercial relationship. Such a transition had already taken place within Scandinavia as Norwegian literature ascended to a leading position and mutual agreements on protection of copyright around 1880 put an end to what Norwegian authors considered unfavourable treatment by Danish and Swedish theatres (Fulsås and Rem 2018, 73-74). In Germany in the 1890s, Ibsen welcomed competition that forced Fischer to pay him higher and higher fees for the privilege of being first in the German market (ibid., 188-92). In 1892, William Heinemann traveled to Norway to negotiate exclusive rights to The Master Builder, without knowing what it was about (St John 1990, 120), something that would have been unthinkable just a decade earlier. In 1899, Ibsen was furious when Heinemann threatened to pay half the promised fee for When We Dead Awaken because of delays from Gyldendal: 'I will not receive half a fee from Mr. Heinemann. I will, however, present him with the entire fee, which he can keep on the condition that I for the future will be spared any association with him' (Letter to Archer, 16 December 1899, quoted and transl. in Fulsås and Rem 2018, 198). In the end, however, his last play was nevertheless published by Heinemann.

We ought to underline that Ibsen was by no means representative; no other Nordic author achieved the same status. It was only 'Ibsen' among 'the four greats' of Norwegian literature who became stabilized within a relatively permanent, strong-tied international 
network. Bjørnson only did it temporarily. Gosse edited Bjørnson's collected novels in thirteen volumes 1895-1909, published by Heinemann (St John 1990, 79), and in Germany, Albert Langen had taken over Bjørnson's affairs around the same time. Between 1895 and 1904, Langen published 20 Bjørnson titles in a total number of 83,000 copies, while Ein Fallissement and Über den Kraft were bestsellers with Reclam. Bjørnson and Langen's commercial relations were cemented by Langen's marriage with Bjørnson's daughter Dagny. When the marriage broke up, Bjørnson terminated his publishing business with his former son-in-law and offered his last work to Langen's enemy Fischer (Keel 1986, 30, 39; Keel 1999, 346-47, 514-15). Jonas Lie and Alexander Kielland never managed to enter into stable and mutually favourable publishing relations outside Scandinavia. Their relations to foreign markets continued to be characterized by asymmetry and exploitation and they received negligible payments from Britain and continental Europa.

At the same time, we should add that literary 'exploitation' was not just a matter of peripheral authors being plundered by 'imperial' powers. The Scandinavian countries, economies with a huge net import of literature, thought they were not able to afford paying both translator and author, and therefore did not join the Berne convention on the protection of authors' rights, until the turn of the century. English, French, and German authors generally received no payments from translations into Nordic languages. On the other hand, of course, it had more serious financial implications to be unprotected in large markets than in smaller ones.

Ibsen also stands out for having survived as world literature after the 'Scandinavian moment' - together with Strindberg, we might say, but ahead of him. In parallel with free trade being replaced by protectionism, particularism and eventually war, the favourable reception of foreign literatures was replaced by growing nationalism and diminished circulation. Paradoxically, this was most radically so in the self-proclaimed capital of world literature, Paris. By the middle of the 1890s, a forceful nationalist reaction set in against the 'cosmopolitans', with Ibsen as a central topic of debate. Lemaître contributed significantly to this new national turn and even Zola joined him at one point (Shepherd-Barr 1997, 163-64). Ibsen's main and authorised translator in French, Moritz Prozor, was exasperated by what he saw as Parisian protectionism. One consequence of this nationalist counter-current was that Ibsen did not have the same transformative impact on French drama as he had on German (particularly associated with Gerhard Hauptmann) and English (particularly associated with Shaw). While one of the ambitions of the French Théâtre Libre had been to inspire a renewal 
of national drama, the avant-garde mainly had to keep relying on the foreign repertoire. By the first decades of the twentieth century, French theatre had, in the words of one theatre scholar, 'reached an almost unparalleled low point' with no native playwright to compare with Ibsen, Strindberg or Chekov (quoted in Shepherd-Barr 2012, 68).

In Germany, too, the literary traffic with Scandinavia became less intense. To Fischer, the inflow from the Nordic countries had been vital to his business all from he started up in Berlin with Rosmersholm in 1887. From around 1910, this inflow was not as rich as before. Ibsen's status was not affected, however. When the war broke out in 1914, Samuel Fischer, writing on 'Patriotismus und Literatur', felt certain that the military frontlines would have literary implications, his main example being Gabriele d'Annunzio whom he would not have in his catalogue any more. His Scandinavian authors would not be affected, though, since these countries were neutral, and Ibsen would in any case be above such considerations: 'Ich bin der Verleger Ibsens. Ibsen ist durch seine innerliche Wirkung zu einem deutschen Dichter geworden' (quoted in Mendelssohn 1970, 691). In 1907, Fischer published a 'Volksausgabe' of Ibsen's 'sämtliche Werke' in five volumes, which became a huge success. By the end of the First World War he had printed 70,000 volumes and ten years later 110,000 (ibid., 24748). At the same time, Reclam continued to distribute Ibsen in millions of copies in their cheap Universalbibliothek, a total of 4, 5 million by 1917 and nearly 6, 1 million by 1943 (Keel 1992, 145).

The Ibsen case does not fit well into a strictly Paris-centred model of world literary space. What was arguably most important for Ibsen in the long run was his early canonisation in English. With the rise of English as a global language in the twentieth century, this became decisive for his continued position in world literature and drama and something hardly achieved by any other Scandinavian author of his generation. Already by the early decades of the twentieth century, Ibsen had started reaching beyond the European world, to India, Japan, and China. In Ibsen's case, then, the degree of symmetry he managed to achieve towards major appropriating cultures in his own lifetime became decisive for his standing in the international canon. 


\section{References}

Ahlström, Stellan. 1956. Strindbergs erövring av Paris. Stockholm: Almqvist \& Wiksell.

Anon. 5 April 1890. Ibsen for the English. The Speaker, 379-80.

Anon. 10 July 1897. Ibsen in Translation. The Speaker, 41-42.

Apter, Emily. 2013. Against World Literature. London: Verso.

Archer, William. 17 September 1892. Mr Archer Protests The National Observer, vol. 8, 456.

Archer, William. 1897. Translator's Note. In Ibsen, John Gabriel Borkman, ix-x. London: Heinemann.

Archer, William. 1908. General Preface. The Collected Works of Henrik Ibsen. Vol. 1. London: Heinemann.

Archer, William. [1893] 1972. The Mausoleum of Ibsen. In Henrik Ibsen: The Critical Heritage, ed. Michael Egan, 304-12. London: Routledge and Kegan Paul.

Archer, William. [1901] 1984. The Real Ibsen. In William Archer on Ibsen: The Major Essays, 1889-1919, 53-68. London: Greenwood Press.

Aveling, Edward. Jan-Jun 1884. 'Nora' and 'Breaking a Butterfly'. To-Day, vol. 1, 473-75.

Bassnett, Susan. 2003. Translation Studies. London: Routledge.

Cima, Gay Gibson. 1993. Performing Women. London: Cornell University Press.

d'Amico, Giuliano. 2013. Domesticating Ibsen for Italy. Turin: Edizioni di Pagina.

Damrosch, David. 2003. What Is World Literature? London: Princeton University Press.

Egan, Michael. 1972. Ibsen: The Critical Heritage. London: Routledge and Kegan Paul.

Ellis, Havelock. July-Dec 1884. Women and Socialism. Vol. 2, 351-63.

Fletcher, John and James McFarlane. 1976. Modernist Drama: Origins and Patters, in Modernism, ed. Malcolm Bradbury and James McFarlane, 499-513. Harmondsworth: Penguin.

Fulsås, Narve and Tore Rem. 2018. Ibsen, Scandinavia and the Making of a World Drama. Cambridge: Cambridge University Press.

Gosse, Edmund. January 1 to June 1 1873. Ibsen, the Norwegian Satirist. Fortnightly Review, vol. 19, 74 .

Gosse, Edmund. January 1889. Ibsen's Social Dramas. Fortnightly Review, vol. 51, 116.

Gross, John. 1969. The Rise and Fall of the Man of Letters. London: Weidenfeld and Nicolson.

Holledge, Julie and Jonathan Bollen, Frode Helland and Joanne Tompkins. 2016. A Global Doll's House: Ibsen and Distant Visions. London: Palgrave. 
Ibsen, Henrik. Brev [Henrik Ibsen's Letters], ed. Narve Fulsås. In Henrik Ibsens Skrifter, ed. Vigdis Ystad: https://www.ibsen.uio.no/brev.xhtml.

Keating, Peter. 1989. The Haunted Study. London: Secker \& Warburg.

Keel, Aldo. 1986. Einleitung, Bjørstjerne Bjørnsons Briefwechsel mit Deutschen, ed. Aldo Keel, vol 1. Basel and Frankfurt am Main: Helbing \& Lichtenhahn).

Keel, Aldo. 1992. Reclam under der Norden. In Reclam: 125 Jahre Universalbibliothek $1867-$ 1992, ed. Dietrich Bode, 132-47. Stuttgart: Philipp Reclam jun.

Keel, Aldo. 1999. Bjørnstjerne Bjørnson: En biografi, 1880-1910. Oslo: Gyldendal.

Lord, H.F. 1882. Life of Henrik Ibsen. In Nora, vii-xxiv. London: Griffith and Farran.

Marx, Eleanor. 8 May 1890 and 16 May 1890. H.L. Brækstad Collection, Letter coll. 17, Norwegian National Library.

Mendelssohn, Peter de. 1970. S. Fischer und sein Verlag. Frankfurt am Main: S. Fischer.

Moretti, Franco. 1986. The Moment of Truth. New Left Review, 159, Sept-Oct, 39-48.

Moretti, Franco. 1998. Atlas of the European Novel 1800-1900. London: Verso.

Nyholm, Kela. 1959. Henrik Ibsen paa den franske scene. Ibsenårbok 1957-59, 7-78.

Osterhammel, Jürgen. 2014. The Transformation of the World: A Global History of the Nineteenth Century. Princeton: Princeton University Press.

Ray, Catherine. 1876. Henrik Ibsen. In The Emperor and Galilean, trans. Catherine Ray, iiixiv. London: Samuel Tinsley, 1876.

Robins, Elizabeth. 1928. Ibsen and the Actress. Edinburgh: Neill.

Scott, Clement. July 1889. 'A Doll's House'. The Theatre, vol. 14, 19-22.

Scott, Clement. 8 June 1889. Unsigned notice. Daily Telegraph, 3.

Shepherd-Barr, Kirsten. 1997. Ibsen and Early Modernist Theatre, 1890-1900. Westport, Conn.: Greenwood Press.

Shepherd-Barr, Kirsten. 2012. Ibsen in France from Breakthrough to Renewal. Ibsen Studies, vol. 12 , no. $1,56-80$.

St John, John. 1990. William Heinemann: A Century of Publishing 1890-1990. London: Heinemann.

Templeton, Joan. 2018. Shaw's Ibsen: A Re-Appraisal. New York: Palgrave Macmillan.

Thwaite, Ann. 1984. Edmund Gosse. London: Secker \& Warburg.

Wedmore, Frederic. 15 June 1889. Ibsen in London, The Academy, vol. 35, 419-20. 